\title{
167 鼻副鼻腔癌患者のリンパ球幼若化反応
}

\author{
杉田公一井上憲文 \\ （東大耳鼻咽喉科）
}

鼻副鼻腔癌患者の細胞性免疫能を知る手がかり の一つとして、P H A および Con A によるリン 八゚球幼若化反応を経時的に調べ、両者を比較した。 対象は上䫇癌 12 例。リンパ球幼若化反応は全 血微量法を用い、術前より経時的に測定した。 P H A 12 例全例に、Con A は 8 例に対し行な っている。

Con A による幼若化の変動を非癌症例 2 例（血 管腫と術後性頓 部襄胞 ) と比較すると、非癌症例 ではあらかじめ求めた正常者 22 例の範囲（40 〜 $\left.60 \times 10^{3} \mathrm{c} \mathrm{pm}\right)$ の限よりはじまり、術後、 次第に上昇するが、担癌例では $10 \sim 30 \times 10^{3}$ c pmとかなり低い。

P H A、Con Aによる幼若化能の経時的変動《 常にP H A がCon A より大きいが、両者はほぼ平 行して変動する。細くみると、P H A は術後 2 週 目、6力月目を除き、次第に上昇するが、Con A は 4 日目に低下し、以後はほとんど横ばいである。 末梢血リンパ球数と P H A / Con A の比をみる と、術後 4 日目にリンパ球数は减少し、 $\mathrm{P} / \mathrm{C}$ 比 はCon Aの低下のため上昇している。これを除く
と、リンパ球数は 2000 付近、 $\mathrm{P} / \mathrm{C}$ 比は 2 付近 でほぼ一定である。

P H A および Con A によるリンパ球幼若化反応 は、近年さかんに研究されているが、Con A は Suppressor $\mathrm{T}$ あるいは F c R ${ }^{+} \mathrm{T}$ 細胞活性をより 反映すると言われ、P H Aによる幼若化と相反す る結果を得られるように思われたが、我々の研究 では、幼若化は P H A がCon Aより常に高く、術 後 4 日目を除き両者はほぼ平行して変動し、PHA /Con A 比は約 2 という結果を得た。

質問

高橋光明 (旭医大 耳鼻科)

1) P H A、Con A の培養日数は?

2） Con $\mathrm{A}$ は $\mathrm{T}$ cell subset のどの細胞に㗢いて いると考えるか。

解答杉田公一(東大耳鼻科)

P H A、Con A ともに 72 時間で、培養時間は 一定である。

Con Aの上昇は病態の悪化を示し、PHA < Con A となるといわれているが、今回の我々の検 討した症例では、P H A > Con Aであった。 